УДК 378.011-053.6

DOI:

Олександр Ворохаєв, аспірант кафедри соџіальної роботи та освітніх і педагогічних наук Наиіонального університету “Чернігівський колегіум” імені Т.Г. Шевченка

\title{
НАУКОВІ ПІДХОДИ ДО ПРОБЛЕМИ ЗДОРОВ'ЯЗБЕРЕЖУВАЛЬНОЇ ДІЯЛЬНОСТІ В ЗАКЛАДАХ ВИЩОЇ ОСВІТИ
}

У статті констатовано, щуо правильний спосіб життя учасників освітнього процесу залежить від використання здоров'язбережувальних технологій в освітніх закладах України. Встановлено, щзо існують різні наукові підходи до проблеми здоров'язбережувальної діяльності та правильного способу життя студентів вишів.

Розглядаються умови здоров'язбережувальної діяльності та зміст здоров'язбережувальної компетентності майбутніх сочіальних працівників. Констатовано, щчо необхідно проводити превентивні заходи, які сприятимуть здоров'язбереженню й правильному способу життя студентів спеціальності "Соціальна робота".

Ключові слова: студенти університету; здоров'я; здоров'язбереження; правильний спосіб життя; освітній процес; заклад вищьої освіти.

Jim. 11.

Oleksandr Vorokhayev, Postgraduate Student of the Social Work and Educational and Pedagogical Sciences Department Taras Shevchenko National University "Chernihiv Colehium"

\section{SCIENTIFIC APPROACHES TO THE PROBLEM OF HEALTH ACTIVITY IN HIGHER EDUCATION INSTITUTIONS}

The correct way of life of participants in the educational process depends on the use of health technologies in educational institutions of Ukraine. Domestic scientists believe that among university students there is sometimes a negative attitude towards the formation of a healthy lifestyle and physical culture as subjects.

The purpose of the article is to analyze scientific approaches to the problem of health care and the right way of life of students of higher education institutions.

Researchers have identified different types of life: prosperous (characterized by high quality of life and good health throughout life); satisfactory; bad. Today, technologies for ensuring a prosperous (correct) life remain poorly studied. The concept "proper lifestyle" in education is closely linked to the definition of health as a state of completed physical, mental and social well-being. The indicator of health is not only the absence of disease, but harmonious nervous and mental development, high mental and physical performance. There are many conditions for health activities: systematic implementation of social programs for cultivating a healthy lifestyle; raising the level of physical education; acquisition of skills of analysis of information that affects health, sports, sleep, healthy eating. The health competence of future social workers is a set of systematic knowledge and ideas about the positive and negative changes in the health of all participants in the educational process and the ability to develop an effective program to preserve the health of students in the educational process. Scientists claim that physical education alone is not able to fully ensure a sufficient level of physical activity of university students, to promote their health and proper lifestyle.

Conclusions. The results of the study allow us to conclude that: 1. Nowadays, there are many scientific approaches to the problem of health and the right way of life. Which have in common and different in the works of domestic and foreign scientists. 2. The main condition of health care activities in higher education institutions is the personal involvement of participants in the educational process in health care activities.

Keywords: university students; health; health saving, the right way of life; an educational process; an institution of higher education.

П

остановка проблеми. Заклади вищої освіти безпосередньо мають сприяти здоров'ю та розв'язувати проблеми збереження здоров'я і правильного способу життя студентів вищої школи. Необхідність у здоров'язбережувальній діяльності закладів вищої освіти зумовлена тим, що при виконанні свого першочергового завдання - надання можливості отримання вищої освіти - виникає небезпека зниження здоров'я студентів унаслідок

перевантаження та гіподинамії. Правильний спосіб життя учасників освітнього процесу залежить від використання здоров'язбережувальних технологій в освітніх закладах України. Маємо зазначити, що заняття фізичною культурою не здатні повною мірою забезпечити достатній рівень рухової активності студентів університетів, сприяти зміцненню їхнього здоров'я та налагодженню правильного способу життя.

Невирішеними раніше частинами

Молодь і ринок №3-4 (182-183), 2020 


\section{НАУКОВІ ПІДХОДИ ДО ПРОБЛЕМИ ЗДОРОВ' ЯЗБЕРЕЖУВАЛЬНОЇ ДІЯЛЬНОСТІ В ЗАКЛАДАХ ВИЩОЇ ОСВІТИ}

проблеми вважаємо вивчення інертного типу діяльності та поведінки в освітньому процесі.

Актуальність проблеми. Вивчати проблему здоров'язбережувальної діяльності у сучасних закладах вищої освіти необхідно. Вітчизняні науковці вважають, що серед студентів університетів існує іноді негативне ставлення до формування здорового способу життя та фізичної культури як навчальних предметів. Анонімне анкетування студентів бакалаврату дало можливість 3'ясувати проаналізувати, що багато 3 них мають негативні звички.

Аналіз останніх досліджень і публікацій. На сьогоднішній день поняття “правильний спосіб життяо досліджено О. Приступою [11]. У вітчизняній науковій літературі існують роботи із здоров'язбереження у вищій школі: Д. Вороній, С. Грищенко, Г. Мешко, М. Носко, Ю. Носко [5; 8; 9]. Серед зарубіжних дослідників маємо відзначити О. Василевську, Ю. Павлову [4; 10].

Малодослідженими на сьогодні залишаються складові та умови забезпечення правильного способу життя, що $є$ необхідними для збереження здоров'я студентів закладів вищої освіти в Україні.

Мета статті - проаналізувати наукові підходи до вивчення здоров'язбережувальної діяльності та правильного способу життя студентів закладів вищої освіти.

Матеріали і методи дослідження: теоретичний аналіз і узагальнення даних науково-методичної літератури, педагогічні спостереження, анкетування. У дослідженні взяли участь респонденти 3 психолого-педагогічного факультету Національного університету “Чернігівський колегіумо імені Т.Г. Шевченка: 12 викладачів, 28 студентів 2-4-х курсів бакалаврату спеціальності “Соціальна роботао. Запитання оцінювали за шкалою від 1 до 5 балів.

Виклад основного матеріалу. У закладах вищої освіти був запроваджений навчальний курс “Формування здорового способу життя”, що сприяло активному залученню молоді до здоров'язбереження та правильного способу життя.

Вітчизняна дослідниця О. Приступа доводить, що “у освітній галузі поняття “правильний спосіб життя” тісно пов'язане 3 визначенням здоров'я як стану повного фізичного, психічного і соціального благополуччя" $[11,35]$. Стверджуючи це можна виділити такі різновиди життя: благополучне (характеризується високою якістю життя та хорошим здоров'ям впродовж усього життя); задовільне; погане. Малодослідженими на сьогодні залишаються технології забезпечення благополучного (правильного) життя, що необхідні для збереження здоров'я студентської молоді в Україні.

Зарубіжна вчена Ю. Павлова стверджує необхідність превентивних заходів, що сприятимуть запровадженню як здоров'язбереженню, так й правильному способу життя студентів закладів вищої освіти: “Оцінювання превентивних заходів освітнього закладу проводили за низкою показників" $[10,60]$, що фактично є індикаторами компонентів правильного способу життя: “фізична складова правильного способу життя - "Творчі види діяльності"; психологічна та соціальна складова - “Дружня обстановка у освітньому закладі", "Відсутність фізичного покарання та насильства”, “Протидія булінгу та дискримінаціі”; соціальна активність, “Співпраця та активне навчання"; розвиток та самоідентифікація “Прийняття рішень студентами”, “Якісна превентивна освіта", “Співпраця та активне навчання"; зовнішне середовище - “Санітарногігієнічні умови".

Дослідження Ю. Павлової виявило, що “усі учасники освітнього процесу високо оцінюють превентивні заходи, які стимулюють до дотримання правильного способу життя, що проводиться в освітньому закладі. Середні оцінки були у діапазоні 4,3-4,5 бала. Найнижчий показник спостерігали для параметра “Співпраця та активне навчання" (4,1 бала), найвищий - для “Дружня обстановка у освітньому закладі" $(5,8$ бала), "Протидія булінгу та дискримінації” (3,8 бала), “Прийняття рішень студентами” (5,5 бала), “Якісна превентивна освіта" (4,9 бала). Значення останніх параметрів були достовірно вищими (p $<0,05)$, ніж “Співпраця та активне навчання” [10, $60]$.

На основі аналізу наукових джерел(Г. Апанасенко [1], С. Грищенко [9], А. Домашенко [6], О. Зварищук [7], М. Носко [9], Ю. Носко [9] та ін.) встановлено, що на сучасному етапі спостерігається загальне погіршення показників фізичного стану студентів вищої школи. Натепер вітчизняні та зарубіжні науковці відзначають низький рівень функціональних можливостей та рухової підготовленості студентів. Анатомо-фізіологічні особливості розвитку організму студентів університетів зумовлюють необхідність особливих підходів у диференціації та дозуванні фізичних навантажень у процесі занять фізичними вправами.

Вітчизняні науковці стверджують, що додаткові можливості для оптимізації фізичного стану студентів університетів створюють самостійні оздоровчі тренувальні заняття які $\epsilon$ ефективними тільки за умови адекватного змісту 


\section{НАУКОВІ ПІДХОДИ ДО ПРОБЛЕМИ ЗДОРОВ'ЯЗБЕРЕЖУВАЛЬНОЇ ДІЯЛЬНОСТІ В ЗАКЛАДАХ ВИЩОЇ ОСВІТИ}

та дозування фізичних навантажень. Учені наголошують на обгрунтуванні раціонального змісту самостійних індивідуальних оздоровлювальних тренувальних занять для студентів університетів 3 метою оптимізації їхнього фізичного стан, що особливо важливо для періоду навчання у вищій школі $[3 ; 5 ; 8 ; 9]$.

В університетах України фізичне виховання та спеціальна фізична підготовка є невід'ємними складовими професійної підготовки студентів. Важливим $є$ також те, що систематично впроваджуються соціальні програми культивування здорового способу життя, наприклад, проведення кураторами навчальних груп виховних бесід за темами: “Здоровий спосіб життя”, “Правильне харчування”, “Тютюнопаління та його наслідки”, “Шкідливість вживання алкоголю”, “Наркоманія - дорога в нікуди”, “Недопущення заражень венеричними захворюваннями”, а також систематично проводяться спортивно-масові заходи: змагання, естафети (лижі, туризм), студенти активно відвідують спортивні секції.

Практичні та теоретичні компоненти фізичної оздоровлювальних діяльності виконуються декілька разів на тиждень та є обов'язковими вимогами до освітнього процесу у вишах. Виховання здорового молодого покоління має бути пріоритетним завданням закладів вищої освіти. При цьому потрібно розуміти, що “показником здоров'я є не лише відсутність будь-яких хвороб, а гармонійний нервово-психічний розвиток, висока розумова і перш за все фізична працездатністьо [2, 364; 5, 112].

Форму ранкової гігієнічної гімнастики та індивідуальних оздоровчих тренувальних занять, науковці вважають необхідними для студентів університетів. Через самостійні заняття повинна формуватися звичка до щоденної фізкультурної оздоровлювальної діяльності. Маємо зазначити, що завдання для самостійної роботи тісно пов'язані з матеріалом університетської програми та мають бути спрямовані на оптимізацію фізичного стану студентів.

Н. Беседа доводить, що “у педагогічній практиці здоров'язбережувальна діяльність розуміється як діяльність соціального об'єкта (педагога, закладу), метою якої є створення необхідних умов (організаційно-педагогічних, соціокультурних), що сприяють формуванню i зміцненню здоров'я суб'єктів освітнього процесу, їхньої продуктивної навчально-пізнавальної і практичної діяльності” [2, 64].

Здоров'язбережувальна діяльність безпосередньо пов'язана з рівнем фізкультурної освіти. Низка вітчизняних та зарубіжних учених розкривають проблеми моніторингу у фізкультурній освіті, визначають зміст і технології здійснення моніторингу здоров'язбережувальної діяльності. Розробляються "комплекси тестів і анкет, що включають тести фізичного розвитку, тести рухової підготовки, психофізіологічні тести, соціально-психологічне анкетування, алгоритм визначення здоров' язбережувального потенціалу закладу освітио $[3 ; 5,36 ; 8,18]$.

Практичні кроки щодо розв'язання проблеми збереження і зміцнення здоров'я в сучасних умовах освітнього процесу не можуть не супроводжуватися зверненням до вивчення умов цілеспрямованої побудови бажаної майбутньої професійної складової особливо фахівців соціальної сфери.

Викладачі психолого-педагогічного факультету Національного університету “Чернігівський колегіум” імені Т.Г. Шевченка спеціальності “Соціальна робота" мають спрямовувати освітній процес на оздоровлювальні та інші заходи, визначати оптимальні форми, методи і напрями цього процесу. Це важливо для формування здорового способу життя студентів.

Запровадження здоров'язбережувальної діяльності викладачем закладу вищої освіти - це важливий компонент його професійної діяльності, який включає педагогічні дії, що грунтуються на усвідомленні мети здоров'язбережувальної діяльності, способів, прийомів, методів і форм їі досягнення. Такі дії допомагають зводити в єдину систему всі здоров'язбережувальні дії. “'Здоров’язбережувальна діяльність є складною, за своєю сутністю і змістом, комплексною і міждисциплінарною проблемою, має різні види та прояви. Відповідно, методологічні підходи, педагогічні методи, принципи та засоби розв'язання проблеми здоров'язбережувальної діяльності перебувають у сфері міжпредметного знання" $[4,76]$

Отже, умови здоров'язбережувальної діяльності $€$ провідним видом професійної діяльності майбутнього соціального працівника та має інтелектуальний характер. Основне призначення здоров'язбереження полягає у дослідженні, передбаченні, прогнозуванні, оцінюванні результатів реалізації тих чи інших дидактичних, виховних, розвивальних задумів зміцнення і збереження здоров'я учасників освітнього процесу шляхом створення спеціальних інтелектуальних засобів трансформації задумів через нові здоров'язбережувальні технології, методики, системи діяльності як педагогів, так і студентів, особливо спеціальності “Соціальна робота". 


\section{НАУКОВІ ПДХОДИ ДО ПРОБЛЕМИ ЗДОРОВ'ЯЗБЕРЕЖУВАЛЬНОЇ ДІЯЛЬНОСТІ В ЗАКЛАДАХ ВИЩОЇ ОСВІТИ}

\begin{abstract}
Майбутні спеціалісти соціальної сфери мають бути навченими основних умов здорового способу життя, а саме: набуття навичок аналізу інформації, яка впливає на здоров'я, спорт, сон, здорове харчування та інші фактори, систематизувати й класифікувати ¥ї; висувати гіпотези та ідеї; обговорювати результати наукових досліджень.

Зазначимо, що нами проведено комплексне вивчення стануумов організаціїздоров'язбережувальної діяльності в Національному університеті “Чернігівський колегіум” імені Т.Г. Шевченка. Основними об'єктами аналізу були: здоров'язбережувальний потенціал студентів психолого-педагогічного факультету університету; стан здоров'я, рівень фізичного розвитку й фізичної підготовленості студентів; спосіб життя, який впливає на здоров'я; режим праці та відпочинку студентів; ставлення студентів до здоров'я та правильного способу життя; культура здоров'я майбутніх соціальних працівників та психологів і ії̈ значення для майбутньої професійної діяльності.
\end{abstract}

Для вивчення особливостей способу життя студентів психолого-педагогічного факультету, які впливають на здоров'я, нами була використана анкета-опитувальник.

Результати анкетування показали, що спосіб життя студентів характеризується пасивним проведенням часу при недостатній руховій активності, обсяг фізичних вправ, необхідний для нормального фізичного розвитку, не виконують 73,2 \% хлопців і 67,4 \% дівчат.

Проведене дослідження дало змогу визначити умови, при яких реалізація здоров'язбережувальної діяльності буде ефективною: інтеграція освітнього й оздоровлювального процесу в єдиний функціональний комплекс; організація рухового режиму і фізкультурно-оздоровлювальної роботи; організація роботи з формування цінності здоров'я та здорового способу життя; організація моніторингу результатів реалізації здоров'язбережувальної діяльності.

Для нашого дослідження також важливою умовою $є$ підвищення професійно-педагогічної компетентності майбутніх соціальних працівників у сфері теорії та методики здоров'я, здоров'язбережувального освітнього процесу. Відтак здоров'язбережувальна компетентність студентів бакалаврату насамперед становить комплекс систематичних знань і уявлень про позитивні й негативні зміни у стані здоров'я всіх учасників освітнього процесу; уміння складати дієву програму збереження здоров'я студентів в умовах освітнього процесу. Зазначена умова, на нашу думку, є провідною у змісті здоров'язбережувальної компетентності студентів спеціальності "Соціальна робота".

Отже, майбутні фахівці спеціальності “Соціальна робота" повинні бути готовими до формування здоров'язбережувальної компетентності як своєї, так і осіб, що потребують послуг в соціальній cферi.

Висновки. Отримані в ході дослідження результати дають можливість дійти висновку про те, що: 1. Сьогодні існує багато наукових підходів до здоров'язбереження та правильного способу життя. Які мають спільне та відмінне у працях вітчизняних та зарубіжних вчених. 2. Основною умовою здоров'язбережувальної діяльності у закладах вищої освіти $\epsilon$ особистісне включення учасників освітнього процесу у здоров'язбережувальну діяльність.

Перспективами подальших наукових розвідок у цьому напрямі вважаємо ретельне вивчення правильного способу життя студентами спеціальності “Соціальна робота”.

\section{ЛІТЕРАТУРА}

1. Апанасенко Г. Л., Попова Л. А. Медицинская валеология. Ростов-на-Дону: Феникс, 2000. 248 с. (Серия “Гиппократ").

2. Беседа Н. А. Підвищення готовності вчителів загальноосвітньої школи до застосування здоров'язбережувальних технологій. Педагогічні науки: теорія, історія, інноваційні технології. 2010. 1 (3). С. 363-369.

3. Бобрицька В. І. Формування здорового способу життя у майбутніх учителів. Полтава: ТОВ Поліграфічний центр “Скайтек”, 2006. 431 с.

4. Василевская Е. А. Профессиональное здоровье педагога как фактор совершенствования здоровьесберегающей образовательной среды. Вектор науки ТГУ. 2011. 1 (IS). С. 375-378.

5. Вороній Д. С. Формування здоров'язберігаючої компетентності студентів вищих навчальних закладів засобами фізичного виховання: дис. ... канд. пед. наук: спец. 13.00.07. Херсон, 2006. 320 с.

6. Домашенко А. В. Физическая подготовленность и здоровье населения - приоритетная задача государственного строительства. Фізична підготовленість та здоров'я населення. Одеса, 1998. C. $10-12$.

7. Зварищук О. М. Виховання відповідальності старшокласників за свій фізичний стан: дис. ... канд. пед. наук з фіз. вих. та спорту : 24.00.02. Львів, 2002. 198 с.

8. Мешко Г. М. Формування компетентності здоров'язбереження у майбутніх педагогів. Професійні компетениії та компетентності вчителя: Матеріали регіонального наук.- 


\section{НАУКОВІ ПІДХОДИ ДО ПРОБЛЕМИ ЗДОРОВ'ЯЗБЕРЕЖУВАЛЬНОЇ ДІЯЛЬНОСТІ В ЗАКЛАДАХ ВИЩОЇ ОСВІТИ}

практ. семінару. Тернопіль: Вид-во ТИПУ ім. В. Гнатюка, 2006. С. 17-21.

9. Носко М. О., Грищенко С. В., Носко Ю. М. Формування здорового способу життя : навчальний посібник. Київ: “МП Леся”. 2013. 160 с.

10. Павлова Ю. А. Моделирование теоретической структуры качества жизни населения. Современные проблемы формирования и укрепления здоровья: Тез. докл. V Междунар. науч.-прак. конф., Брест, 23-24 октября 2015. Брест: Альтернатива, 2015. С. 59-60.

11. Prystupa E., Pavlova Iu. Evaluation of Health in Context of Life Quality Studying. Advances in Rehabilitation. 2015. V. 29, № 2. P. 33-38.

\section{REFERENCES}

1. Apanasenko, G. L. \& Popova, L. A. (2000). Medicinskaja valeologija [Medical valeology]. Rostovna-Donu.[in Russian].

2. Beseda, N. A. (2010). Pidvyshhennja ghotovnosti vchyteliv zaghaljnoosvitnjoji shkoly do zastosuvannja zdorovjazberezhuvaljnykh tekhnologhij. [Improving the readiness of secondary school teachers to use health technologies]. Pedagogical sciences: theory, history, innovative technologies. Vol.1 (3), pp.363-369.[in Ukrainian].

3. Bobrycjka, V. I. (2006). Formuvannja zdorovogho sposobu zhyttja u majbutnikh uchyteliv [Formation of a healthy lifestyle in future teachers]. Poltava, 431p. [in Ukrainian].

4. Vasilevskaja, E. A. (2011). Professionalnoe zdorove pedagoga kak faktor sovershenstvovanija zdorovesberegajushhej obrazovatelnoj sredy [Professional health of a teacher as a factor in improving a health-preserving educational environment]. Science vector. Vol.1 (IS), pp.375378. [in Russian].

5. Voronij, D. Je. (2006). Formuvannja zdorovjazberighajuchoji kompetentnosti studentiv vyshhykh navchaljnykh zakladiv zasobamy fizychnogho vykhovannja [Formation of health- preserving competence of students of higher educational institutions by means of physical education]. Candidate's thesis. Kherson, 320 p.[in Ukrainian].

6. Domashenko, A. V. (1998). Fizicheskaja podgotovlennost i zdorove naselenija - prioritetnaja zadacha gosudarstvennogo stroitelstva [Physical fitness and health of the population is a priority task of state building]. Physical fitness and health of the population. Odesa. pp.10-12. [in Russian].

7. Zvaryshhuk, O. M. (2002). Vykhovannja vidpovidaljnosti starshoklasnykiv za svij fizychnyj stan [Educating high school students for their physical condition]. Candidate's thesis. Lviv, 198 p.[in Ukrainian].

8. Meshko, Gh. M. (2006). Formuvannja kompetentnosti zdorovjazberezhennja u majbutnikh pedaghoghiv [Formation of health competence in future teachers]. Profesiyni kompetentsii ta kompetentnosti vchitelya: Materiali regionalnogo nauk.-prakt. seminaru - Professional and teacher competencies: Materials of the regional scientific-practical seminar. (pp.17-21).Ternopil. [in Ukrainian].

9. Nosko, M. O., Hryshchenko, S. V. \& Nosko, Ju. M. (2013). Formuvannja zdorovogho sposobu zhyttja [Building a Healthy Lifestyle]. Tutorial. Kyiv, 260 p. [in Ukrainian].

10. Pavlova, Ju. A. (2015). Modelirovanie teoreticheskoj struktury kachestva zhizni naselenija [Modeling the theoretical structure of the quality of life of the population]. Sovremennye problemy formirovaniya i ukrepleniya zdorovya: Tez. dokl. $V$ Mezhdunar. nauch.-prak. konf. - Modern problems of formation and strengthening of health. The bstracts of the $V$ International Scientific and Practical Conference.(pp.59-60). Brest, 23-24 November 2015. [in Russian].

11. Prystupa, E. \& Pavlova, Iu. (2015). Evaluation of Health in Context of Life Quality Studying. Advances in Rehabilitation. Vol. 29, No. 2, pp.3338. [in English].

Стаття надійшла до редакції 10.06.2020

\section{G58080}

\footnotetext{
“Рівність - це єдина і міина основа для суспільного устрою, для порядку, законності, добрих звичаӥв $i$ відбору на високі посади людей, які справді для них придатні".
}

Бернард Жоу

ірландсъкий драматург і публіиист

“Насолоджуйся можливістю постійного зростання”.

Невідомий автор

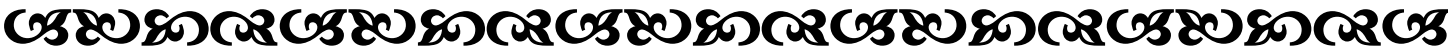

